\title{
Muscular Ventricular Septal Defect
}

National Cancer Institute

\section{Source}

National Cancer Institute. Muscular Ventricular Septal Defect. NCI Thesaurus. Code C124563.

A congenital heart defect resulting from deficient growth or failure of fusion of the muscular component of the ventricular septum. 